\title{
Combined Estimation of Plasma Cell-free DNA Level and Neuron Specific Enolase Activity as Outcome Predictors of Post-resuscitation Patients
}

\author{
Khalid Sallam ${ }^{1}$, Tarek Abo El-Azm ${ }^{2}$, \\ Mamdouh Abadier ${ }^{3}$ \& Ibrahim Rageh ${ }^{4}$ \\ Departments of Neurology ${ }^{1}$, Cardiology ${ }^{2}$, Medical Biochemistry ${ }^{3}$ and \\ Clinical Pathology ${ }^{4}$, Faculty of Medicine, Benha University
}

\begin{abstract}
Objectives: To evaluate the prognostic yield of estimation of plasma cell-free DNA and neuron specific enolase (NSE) activities in post-resuscitation patients concerning survival and neurologic outcome in comparison to Cerebral Performance Category (CPC) score. Patients and Methods: The study included 80 patients developed out-ofhospital cardiac arrest. All patients received mild therapeutic hypothermia irrespective of the initial rhythm. Blood samples were drawn at study inclusion for estimation of plasma cell-free DNA and serum NSE activity. Mortality rate was determined 1-week and 1-month after admission. Neurologic outcomes were evaluated using CPC score collectively as CPC score of 1-2 indicated favorable neurological outcome. Results: 1-week mortality rate was $20 \%$ and throughout a mean ICU stay of 18.4 \pm 10.1 ; range: 3-42 days, another 17 patients died for late mortality rate of $21.3 \%$ and a total mortality rate of $46.3 \%$. At time of discharge 31 patients (38.8\%) were CPC1-2 (Favorable outcome), while 12 patients (14.9\%) were CPC-3 (Unfavorable outcome). Mean plasma DNA and serum NSE activities were significantly higher in CPC3 patients compared to CPC1-2 patients. Survivors had significantly lower at admission plasma cell-free DNA and non-significantly lower serum NSE compared to non-survivors. Survivors had favorable outcome had significantly lower at admission plasma cell-free DNA and serum NSE compared to those had unfavorable neurologic outcome. There was positive significant correlation between plasma cell-free DNA and serum NSE activities and mortality and unfavorable outcome rates. However, the correlation was more significant with plasma DNA than with serum NSE. ROC curve analysis revealed that elevated levels of both parameters could significantly predict the unfavorable neurologic outcome, while high plasma cell-free DNA could significantly predict high mortality rate. Conclusion: At admission plasma levels of cell-free DNA and serum NSE act synergistically for prediction of survival and neurologic outcome of post-resuscitation patients.
\end{abstract}

Keywords: Post-resuscitation, Cell-free plasma DNA, Neuron specific enolase, Mortality, Neurological outcome 


\section{INTRODUCTION}

Optimal survival following sudden cardiac arrest requires heart and brain resuscitation. In patients who achieve cardiac resuscitation, brain recovery from anoxic injury is variable. Neurological sequele ranges from complete recovery to coma with brain death. Thus, ideally outcome assessment would incorporate functional and neurologic status ${ }^{(1)}$.

Overall survival rate from out-ofhospital cardiac arrest has not increased in parallel with the improvements in cardiopulmonary resuscitation $(\mathrm{CPR}){ }^{(2)}$. The hospital discharge rate is $15 \%$ in a metaanalysis that included a total population of over 26,000 patients ${ }^{(3)}$. Additionally, the majority of patients who achieve return of spontaneous circulation after successful CPR have a high risk to death in the post-arrest period. As another problem, is the neurological outcome of the survivors who could escape the mortality risk during the post-arrest period ${ }^{(4)}$.

Functional and neurologic status following cardiac arrest is a more meaningful clinical outcome than simply hospital survival when trying to judge the effectiveness of resuscitation care $^{(5)}$. Functional neurologic status consists of multiple domains including activities of daily living, cognitive function such as memory and abstract thoughts, and emotional health. Ideally then functional and neurologic status would derive from standard, validated, and repeated measures that involve direct subject communication and/or examination. In many circumstances however, the ability to undertake that type of evaluation is not feasible because of limited resources or the practical logistics of subject contact and participation. The Cerebral Performance Category (CPC) score overcomes these challenges because assessment does not require direct subject contact, does not require assessment at specified time points and because it corresponds to quality of life and functional status derived $^{(6,7)}$.

Circulating DNA in plasma is altered both qualitatively and quantitatively in various clinical conditions, including pregnancy, graft rejection trauma, cancer, stroke, myocardial infarction, sepsis, acute pancreatitis and abdominal pain. The exact mechanism of DNA occurrence in blood, however, is not fully understood. Also, knowledge about the elimination of cell-free DNA from blood is inadequate, but available data suggest that more than one mechanism is involved in its clearance ${ }^{(8-10)}$. Cell-free DNA can originate from necrotic cells or apoptotic processes, and active release of DNA fragments from living cells has also been described ${ }^{(11,12)}$.

Immediate post-resuscitation period has some similarities to the sepsis syndrome and septic shock in terms of the inflammatory cascade activation and microcirculatory hypoperfusion. As increased plasma concentrations of cell-free DNA and nucleosomes, in which fragmented DNA is packed during apoptosis, have been found in patients with sepsis and septic shock, and the plasma DNA concentration was found to be an 
independent predictor for ICU mortality in these patients $(13,14,15)$.

Thus, the current study aimed to evaluate the prognostic yield of estimation of plasma cell-free DNA and neuron specific enolase (NSE) activities in post-resuscitation patients concerning survival and neurologic outcome in comparison to Cerebral Performance Category (CPC) score.

\section{PATIENTS \& METHODS}

The current study was conducted at Departments of Neurology, Cardiology and Clinical Pathology, Benha University Hospital in conjunction with Medical Biochemistry Department, Faculty of Medicine through the period since June 2011 till Oct 2012. After approval of the study protocol by the Local Ethical Committee and obtaining written fully informed near patients' relative consent, 80 patients had cardiac arrest were enrolled in the study. Exclusion criteria included failure of resuscitation by emergency health provider, time lapsed since collapse till the start of CPR longer than 15 minutes, no return of spontaneous circulation be achieved within 60 minutes after collapse and history of chronic renal failure, stroke or acute coronary syndrome within the 30 days preceding collapse. Also, trauma patients, pregnant women and patients fulfilling inclusion criteria but died within 24 hours after resuscitation were excluded from the study.

All patients received mild therapeutic hypothermia irrespective of the initial rhythm. Therapeutic hypothermia was initiated after admission with an intravenous infusion of cold saline $\left(4^{\circ} \mathrm{C}, 1000\right.$ to $1500 \mathrm{ml}$ bolus) followed by surface cooling with commercially available non-invasive devices (ArcticSun2000® Medivance, Louisville, Colorado, USA). The target temperature was maintained for 24 hours. All patients received intravenous sedation and analgesia using a combination of midazolam $(0.125 \mathrm{mg} / \mathrm{Kg} / \mathrm{h})$ and fentanyl $(0.002$ $\mathrm{mg} / \mathrm{kg} / \mathrm{h}$ ) in addition to muscle relaxation using repetitive administration of pancuronium (0.1 $\mathrm{mg} / \mathrm{kg}$ ) in order to prevent shivering.

Blood Sampling: Blood samples were drawn at study inclusion for estimation and were divided into two parts:

1. The first part was put in clean dry tube and allowed to clot and then serum was separated in clean dry Eppendorff tube to be stored at $80^{\circ} \mathrm{C}$ till assayed for serum NSE activity using an enzyme immunoassay (Elecsys 2010, Roche Diagnostics GmbH, Mannheim, Germany) ${ }^{(16)}$.

2. The second part was collected in heparinized tubes. Plasma was separated as soon as possible by centrifugation at $1,500 \mathrm{~g}$ for 15 minutes and transferred to acidhandled plastic tubes, which were stored at $-80^{\circ} \mathrm{C}$ till assayed for plasma cell-free DNA level.

Quantification of plasma cell-free DNA:

DNA extraction and quantification of plasma cell-free DNA were performed as described by Saukkonen et al. ${ }^{(17)}$. Briefly, plasma samples were centrifuged at $16,000 \mathrm{~g}$ for 10 minutes before DNA extraction 
to remove any residual cells ${ }^{(\mathbf{1 8 )}}$. DNA was extracted using the QIAamp DNA Blood Mini Kit (Qiagen, Hilden, Germany) according to the "blood and body fluid protocol". Plasma cell-free DNA was measured by real-time quantitative PCR assay for the $\beta$-globin gene using the ABI PRISM 7000 sequence detection system (Applied Biosystems). The sequences were as follows:

Forward primer 5'-GCA CCT GAC TCC TGA GGA GAA-3'

Reverse primer 5'- CAC CAA CTT CAT CCA CGT TCA-3'

PCR cycling conditions were two minutes at $+50^{\circ} \mathrm{C}, 10$ minutes at $+95^{\circ} \mathrm{C}$, and 46 cycles of 20 seconds at $+95^{\circ} \mathrm{C}$ and one minute at $+60^{\circ} \mathrm{C}$. Plasma DNA was measured in duplicate samples. A 10-fold serial dilution of human genomic DNA (Roche Diagnostics GmbH, Mannheim, Germany) was used as a standard curve in the PCR assay. Results are expressed as genome equivalents $(\mathrm{GE}) / \mathrm{ml} ; 1 \mathrm{GE}$ equals 6.6 picograms of DNA. Plasma cell-free DNA concentration of $4,000 \mathrm{GE} / \mathrm{ml}$ was considered as an upper limit of normal range ${ }^{(19)}$.

Clinical evaluation and outcomes:

The basal characteristics of patients and outcomes were evaluated. Mortality rate was determined one week after admission (shock-related mortality) and one-month after admission (late dead from neurological dysfunction including brain death or cardiovascular problem including myocardial infarction). Neurologic outcomes were evaluated using the Cerebral Performance Category (CPC) score collectively as $\mathrm{CPC}$ score of 1-2 indicated favorable neurological outcome, whereas a CPC score of 3-5 indicated unfavorable outcome. In detail; CPC1: normal function, CPC 2: minor disability, CPC 3: severe disability, CPC 4: coma and CPC 5: death ${ }^{\text {(20) }}$.

\section{STATISTICAL ANALYSIS:}

Obtained data were presented as mean $\pm \mathrm{SD}$, ranges, numbers and ratios. Results were analyzed using Wilcoxon; ranked test for unrelated data (Z-test) and Chi-square test $\left(\chi^{2}\right.$ test). Possible relationships were investigated using Pearson linear regression. Sensitivity \& specificity of estimated parameters as predictors for outcome were evaluated using the receiver operating characteristic (ROC) curve analysis judged by the area under the curve (AUC) compared versus the null hypothesis that $\mathrm{AUC}=0.05$. Statistical analysis was conducted using the SPSS (Version 15 , 2006) for Windows statistical package. $\mathrm{P}$ value $<0.05$ was considered statistically significant.

\section{RESULTS}

The study included 80 patients developed out-of-hospital cardiac arrest. There were 59 males $(73.8 \%)$ and 21 females $(26.2 \%)$ with mean age of $63.8 \pm 5.1 ; 49-78$ years. All patients had multiple co-morbidities in varying combinations; however, the presence of underlying cardiac disorder presents the cause of cardiac arrest in 38 patients (47.5\%), 18 patients $(22.5 \%)$ had respiratory failure, 15 patients $(18.8 \%)$ had hypovolemia and 9 patients $(11.3 \%)$ had metabolic disorders.

As regards the initial cardiac arrest rhythm; 70 patients $(87.5 \%)$ had 
either pulseless ventricular tachycardia or ventricular fibrillation, 8 patients $(10 \%)$ had asystole, and only two patients $(2.5 \%)$ had pulseless electrical activity. For resuscitation, more than one resuscitation modality was tried for each patient; however, all received hypothermia as a basic line of management in conjunction with defibrillatory shock wave in 73 patients and 52 patients required coronary reperfusion therapy via PCA for acute coronary syndrome. Mean time elapsed till return of spontaneous circulation (ROSC) since arrival to emergency department was $21.2 \pm 3.6$; range: $12-25$ minutes. However, the majority of patients $(68.8 \%)$ required 20-25 minutes till ROSC, $22.5 \%$ of patients achieved ROSC within 15-20 minutes and only $8.7 \%$ of patients achieved ROSC within 12-15 minutes.

Twenty patients died within the first week after resuscitation for a shock-related mortality rate of $25 \%$. Mean ICU stay was $18.4 \pm 10.1$; range: 3-42 days, throughout ICU stay 17 patients died for late mortality rate of $21.3 \%$ and a total mortality rate of $46.3 \%$. At time of discharge 31 patients $(38.8 \%)$ were $\mathrm{CPC} 1-2$ (Favorable outcome); 13 patients were CPC-1, while 18 patients were CPC2 and 12 patients $(14.9 \%)$ were CPC-3 (Unfavorable outcome), (Fig. 1).

At admission mean levels of plasma DNA and serum NSE activity showed progressive steady increase with increased CPC score. Mean plasma DNA levels estimated in CPC3 patients were significantly $(p<0.05)$ higher compared to both CPC1 and CPC2 patients with nonsignificantly $(p>0.05)$ higher levels in $\mathrm{CPC} 2$ patients compared to $\mathrm{CPC} 1$ patients. Similarly, mean serum levels of NSE activity estimated in CPC3 patients were significantly $(\mathrm{p}<0.05)$ higher compared to CPC1 patients and non-significantly $(p<0.05)$ compared to $\mathrm{CPC} 2$ patients with nonsignificantly $(p>0.05)$ higher levels in $\mathrm{CPC} 2$ patients compared to $\mathrm{CPC1}$ patients, (Table 2).

Categorizing patients according to survival outcome; survivors had significantly $(p<0.05) \quad$ lower at admission plasma cell-free DNA and non-significantly $\quad(p>0.05) \quad$ lower serum NSE activity compared to nonsurvivors, (Fig. 2). Categorizing patients according to neurologic outcome; survivors had favorable outcome significantly $(\mathrm{p}<0.05)$ lower at admission plasma cell-free DNA and serum NSE activity compared to those had unfavorable neurologic outcome, (Table 2, Fig. 3).

There was positive significant correlation between plasma cell-free DNA and serum NSE activities and mortality and unfavorable outcome rates. However, the correlation was more significant with plasma DNA than with serum NSE. On the other hand, high levels of both parameters showed highly significant correlation with unfavorable neurologic outcome rate (Table 3).

Evaluation of predictivity of markers' estimation at time of admission for outcome, ROC curve analysis revealed that elevated levels of both parameters could significantly predict the unfavorable neurologic outcome (Fig. 4), while high plasma cell-free DNA could significantly predict high mortality rate among post-arrest patients, (Table 4, Fig. 5). 
Table (1): Enrollment data of studied patients

\begin{tabular}{|c|c|c|c|c|}
\hline \multicolumn{4}{|l|}{ Data } & Findings \\
\hline \multirow{5}{*}{ Age (years) } & \multirow[t]{4}{*}{ Strata } & \multicolumn{2}{|l|}{$>40-50$} & $2(2.5 \%)$ \\
\hline & & \multicolumn{2}{|l|}{$>50-60$} & $16(20 \%)$ \\
\hline & & \multicolumn{2}{|l|}{$>60-70$} & $60(75 \%)$ \\
\hline & & \multicolumn{2}{|l|}{$>70$} & $2(2.5 \%)$ \\
\hline & \multicolumn{3}{|l|}{ Total } & $63.8 \pm 5.1(49-78)$ \\
\hline \multirow[t]{2}{*}{ Gender } & Males & & & $59(73.8 \%)$ \\
\hline & Females & & & $21(26.2 \%)$ \\
\hline \multirow{6}{*}{\multicolumn{2}{|c|}{ Associated co-morbidities }} & \multicolumn{2}{|l|}{ Obesity } & $50(62.5 \%)$ \\
\hline & & \multicolumn{2}{|l|}{ Diabetes } & $26(32.5 \%)$ \\
\hline & & \multicolumn{2}{|c|}{ Hypertension } & $45(56.3 \%)$ \\
\hline & & \multicolumn{2}{|c|}{ CAD } & $49(61.3 \%)$ \\
\hline & & \multicolumn{2}{|l|}{$\mathrm{CHF}$} & $28(35 \%)$ \\
\hline & & \multicolumn{2}{|c|}{ COPD/emphysema } & $21(26.3 \%) 1$ \\
\hline \multirow{4}{*}{\multicolumn{2}{|c|}{ Cause of arrest }} & \multicolumn{2}{|c|}{$\begin{array}{l}\text { Underlying cardiac } \\
\text { disorder }\end{array}$} & $38(47.5 \%)$ \\
\hline & & \multicolumn{2}{|c|}{ Respiratory failure } & $18(22.5 \%)$ \\
\hline & & \multicolumn{2}{|c|}{ Metabolic disorders } & $9(11.3 \%)$ \\
\hline & & \multicolumn{2}{|c|}{ Hypovolemia } & $15(18.7 \%)$ \\
\hline \multirow{3}{*}{\multicolumn{2}{|c|}{$\begin{array}{l}\text { Initial cardiac arrest } \\
\text { rhythm }\end{array}$}} & \multicolumn{2}{|c|}{ Ventricular fibrillation } & $70(87.5 \%)$ \\
\hline & & \multicolumn{2}{|c|}{ Asystol } & $8(10 \%)$ \\
\hline & & \multicolumn{2}{|c|}{$\begin{array}{l}\text { Pulseless electrical } \\
\text { activity }\end{array}$} & $2(2.5 \%)$ \\
\hline \multirow{3}{*}{\multicolumn{2}{|c|}{ Resuscitation procedure }} & \multicolumn{2}{|c|}{ Therapeutic hypothermia } & $80(100 \%)$ \\
\hline & & \multicolumn{2}{|c|}{ Defibrillatory shock } & $73(91.3 \%)$ \\
\hline & & \multicolumn{2}{|c|}{$\begin{array}{l}\text { Coronary reperfusion } \\
\text { therapy }\end{array}$} & $52(65 \%)$ \\
\hline \multirow{7}{*}{$\begin{array}{l}\text { Time till } \\
\text { ROSC }\end{array}$} & \multirow[t]{6}{*}{ Strata } & $<15 \min$ & Number & $7(8.7 \%)$ \\
\hline & & & Mean \pm SD & $13.6 \pm 3.9$ \\
\hline & & $15-20 \mathrm{~min}$ & Number & $18(22.5 \%)$ \\
\hline & & & Mean \pm SD & $17.6 \pm 7.8$ \\
\hline & & $>20 \mathrm{~min}$ & Number & $55(68.8 \%)$ \\
\hline & & & Mean \pm SD & $23.4 \pm 1.5$ \\
\hline & Total & & & $21.2 \pm 3.6(12-25)$ \\
\hline
\end{tabular}

Data are presented as mean \pm SD \& number; ranges \& percentages are in parenthesis; CAD: Coronary artery disease; CHF: Chronic heart failure; COPD: Chronic obstructive pulmonary disease; ROSC: return of spontaneous circulation 
Table (2): Mean $( \pm \mathrm{SD})$ level of estimated parameters in studied postresuscitation patients categorized according to outcome

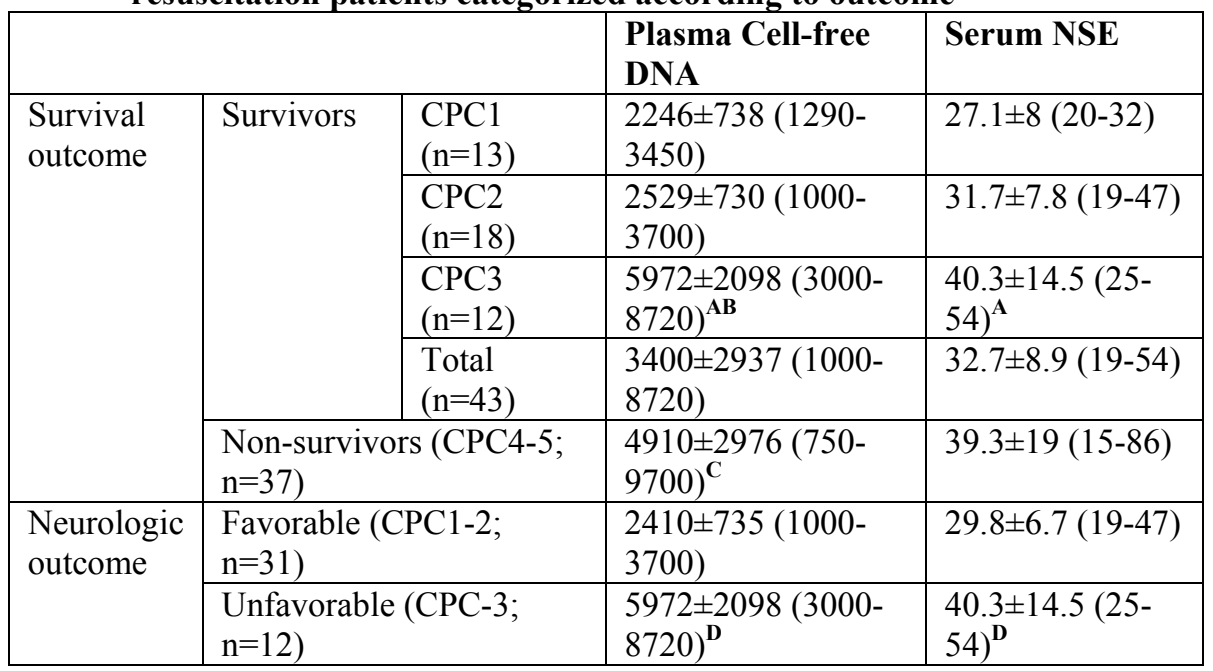

A: significant versus $\mathrm{CPC1}$ patients; $\mathrm{B}$ : significant versus $\mathrm{CPC} 2$ patients; $\mathrm{C}$ : significant versus total survivors; D: significant versus patients had favorable outcome

Table (3): Correlation coefficient " $r$ " between outcome of post-resuscitation patients and estimated parameters

\begin{tabular}{|c|c|c|c|}
\hline & & $\begin{array}{l}\text { Plasma Cell-free } \\
\text { DNA }\end{array}$ & Serum NSE \\
\hline \multirow[t]{2}{*}{ Mortality rate } & $\mathrm{r}$ & 0.289 & 0.224 \\
\hline & $\mathrm{p}$ & $=0.009$ & $=0.046$ \\
\hline \multirow{2}{*}{$\begin{array}{ll}\text { Unfavorable } & \text { neurologic } \\
\text { outcome rate } & \end{array}$} & $\mathrm{r}$ & 0.793 & 0.536 \\
\hline & $\mathrm{p}$ & $<0.001$ & $<0.001$ \\
\hline
\end{tabular}

Table (4): ROC curve analysis for the predictivity of estimated parameters and outcome of post-resuscitation patients

\begin{tabular}{|l|l|l|l|l|l|l|}
\hline \multicolumn{2}{|c|}{} & AUC & Std & Sig. & 95\% CI \\
\cline { 5 - 7 } & & & error & & Lower & Upper \\
\hline \multirow{2}{*}{ Mortality } & Plasma Cell-free DNA & 0.627 & 0.068 & 0.047 & 0.493 & 0.761 \\
\cline { 2 - 7 } & Serum NSE & 0.659 & 0.068 & $>0.05$ & 0.437 & 0.702 \\
\hline \multirow{2}{*}{$\begin{array}{l}\text { Unfavorable neurologic } \\
\text { outcome }\end{array}$} & Plasma Cell-free DNA & 0.956 & 0.032 & $<0.001$ & 0.893 & 1.018 \\
\cline { 2 - 7 } & Serum NSE & 0.805 & 0.080 & $=0.002$ & 0.649 & 0.962 \\
\hline
\end{tabular}

AUC: area under curve; Std error: standard error; Sig.: significance versus the null hypothesis that $\mathrm{AUC}=0.5 ; \mathrm{CI}$ : confidence interval 

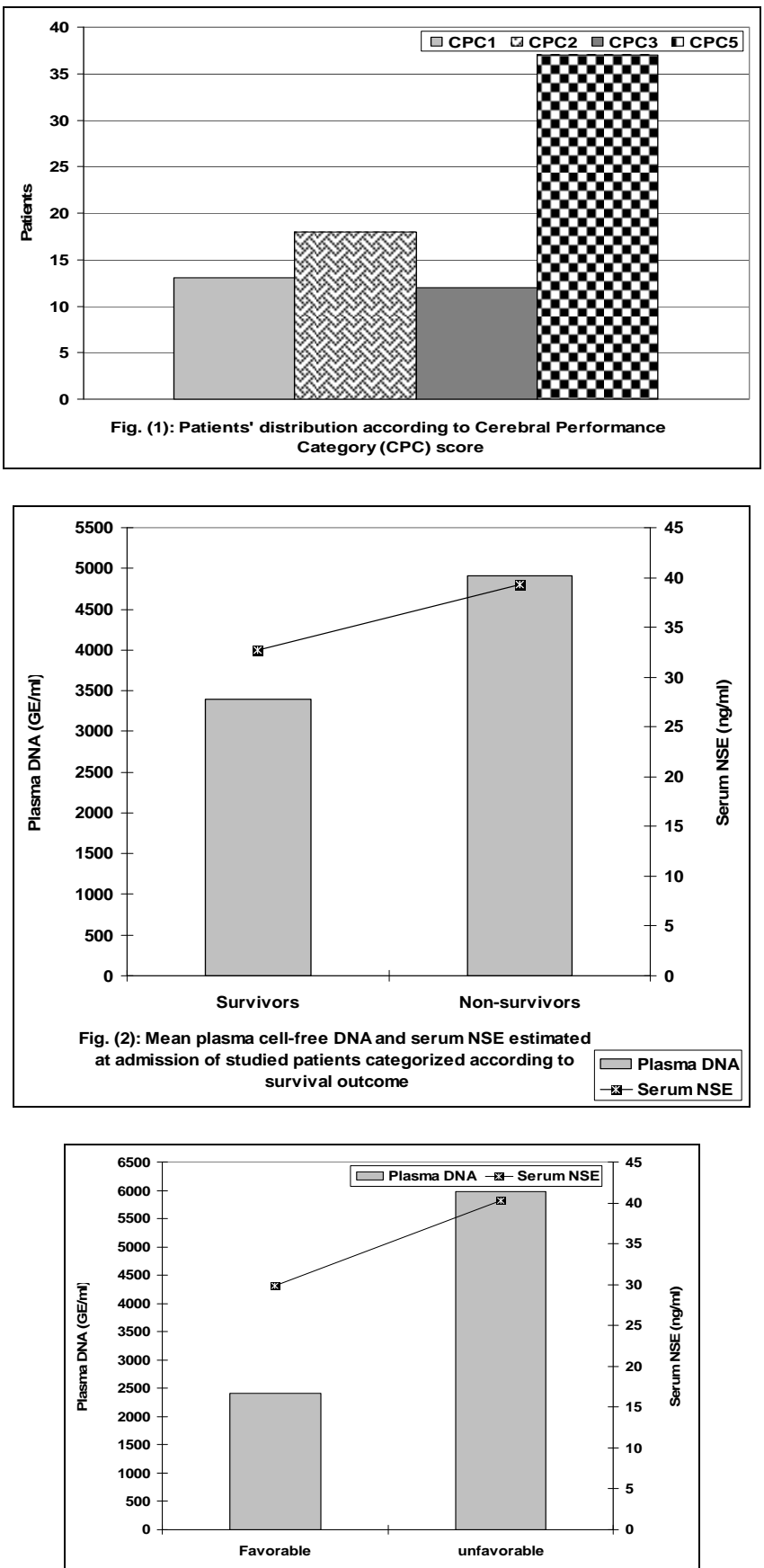

Fig. (3): Mean plasma cell-free DNA and serum NSE estimated at admission of studied patients categorized according to neurologic outcome 


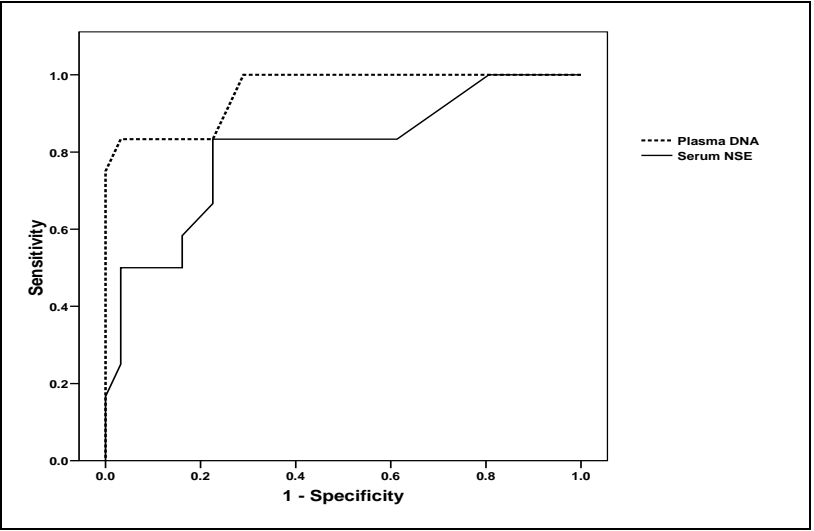

Fig. (4): ROC analysis for both parameters as predictors for neurological outcome

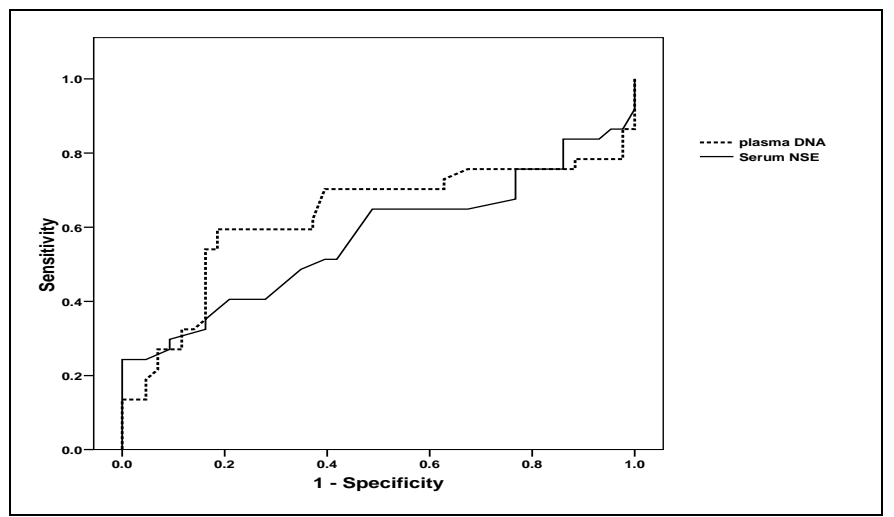

Fig. (5): ROC analysis for both parameters as predictors for vitality outcome

\section{DISCUSSION}

The predictability for outcome of post-resuscitation is critical for both patients and health care providers, so multiple studies tried to evaluate clinical parameters and laboratory markers for prediction of both survival and neurological outcome of these patients ${ }^{(21-24)}$. The current study showed a significantly higher at admission levels of plasma cell-free DNA and serum NSE in non- survivors compared to survivors and in survivors who had favorable neurologic outcome compared to those had unfavorable outcome. However, serum NSE activities showed less prognostic yield for mortality compared to plasma DNA and ROC curve analysis showed high specificity of both parameters for neurological outcome, but plasma level of DNA showed high sensitivity for survival outcome. 
The obtained data supported the previous report concerning the applicability of cell-free DNA plasma level estimation as outcome predictor for critical patients cared at ICU. Saukkonen et al. ${ }^{(25)}$ investigated the concentration of plasma DNA and its association with organ dysfunction and hospital mortality in ICU patients and found the maximum plasma DNA concentration measured during the first 96-hours of intensive care is associated with higher degree of organ dysfunction and disease severity, and the maximum DNA concentration is independently associated with hospital mortality. Okkonen et al. ${ }^{\text {(26) }}$ studied prospectively 580 mechanically ventilated critically ill patients and found that plasma DNA levels were significantly higher in non-survivors than survivors and its level at baseline was an independent predictor of 90day mortality.

Also, the obtained results supported the applicability of plasma DNA estimation as predictor for prognosis of acute attacks as shown by Rainer et al. ${ }^{(27)}$ who studied patients with acute abdominal pain and found that median plasma DNA concentrations were three-fold higher in patients with systemic inflammatory response syndrome, five-fold higher in patients who died within 28 days, and eight-fold higher in patients admitted to ICU and concluded that plasma DNA may have a role in patients with acute abdominal pain as a marker for inflammation and cancer, and a predictor of ICU admission/mortality. Arnalich et al. ${ }^{(28)}$ studied 130 consecutive patients who underwent laparotomy for suspicious of acute mesenteric ischemia (AMI) and found that DNA concentration at admission was significantly higher in patients with AMI and in AMI patients who died compared to those with different diagnosis and concluded that plasma DNA levels may be a useful biomarker in predicting the outcome of patients with AMI.

Concerning the prognostic yield of cell-free plasma DNA level estimation in ischemic neurological affection; Rainer et al. ${ }^{(29)}$ reported significantly higher median plasma DNA concentrations taken within 3 hours of symptom onset in patients had ischemic stroke, intracerebral hemorrhage, and transient ischemic attacks who died compared with those who survived at discharge and correlated with the volume of cerebral hematoma with $100 \%$ sensitivity and $74.4 \%$ specificity for predicting hospital mortality after stroke.

As regards prognosis of postresuscitation patients, the reported data go in hand with those of Arnalich et al. ${ }^{(30)}$ who found plasma DNA concentrations at admission of out-of-hospital cardiac arrest patients were higher in non-survivors at 24 hours than in survivors and were also higher in patients who died in the hospital than in survivors to discharge and concluded that plasma DNA levels may be a useful biomarker in predicting outcome after out-of hospital cardiac arrest. Huang et al. $^{(31)}$ found plasma cell-free DNA level estimated within 2-hours after cardiac arrest was higher in the nonsurvival group than the survival-todischarge group and concluded that the plasma cell-free DNA level increases during the early post-cardiac 
arrest phase and can be an early prognostic factor for out-of-hospital cardiac arrest patients.

As regards NSE, it was found to have has specificity for neurological outcome, that finding could be attributed to the fact that NSE, a gamma isomer of enolase, is located in neurons and neuroectodermal cells so it confers specificity for the damage of nerve cells irrespective of the effect of such damage on survival. Several studies agree that the high NSE serum activity carries the highest predictive value for neurological outcome after resuscitation.

Thus, considering the nonspecific sensitivity of high levels of serum NSE for survival prediction, necessitated the combined estimation of NSE and another predictor for survival, so the current study provided the outcome of combined estimation of serum NSE and plasma DNA for coverage of the probable outcome. In hand with combined biomarker estimation; Topjian et al. ${ }^{(32)}$ found serum NSE activities are associated with neurologic outcome, whereas serum S-100B levels are associated with survival.

It could be concluded that at admission plasma levels of cell-free DNA and serum NSE act synergistically for prediction of survival and neurologic outcome of post-resuscitation patients.

\section{REFERENCES}

1. Moulaert VR, Verbunt JA, van Heugten CM, Wade DT(2009): Cognitive impairments in survivors of out-of-hospital cardiac arrest: a systematic review. Resuscitation 80(3):297305.

2. Fairbanks RJ, Shah MN, Lerner EB, Ilangovan $\mathbf{K}$, Pennington EC, Schneider SM(2007): Epidemiology and outcomes of out-of-hospital cardiac arrest in Rochester, New York. Resuscitation 72(3):41524.

3. Nolan JP, Laver SR, Welch CA, Harrison DA, Gupta V, Rowan K(2007): Outcome following admission to UK intensive care units after cardiac arrest: a secondary analysis of the ICNARC Case Mix Programme Database. Anaesthesia 62(12):1207-16.

4. Gaieski DF, Abella BS, Goyal $M$ (2012): CPR and postarrest care: overview, documentation, and databases. Chest 141(4):1082-9.

5. Raina KD, Callaway C, Rittenberger JC, Holm MB(2008): Neurological and functional status following cardiac arrest: method and tool utility. Resuscitation 79(2):24956.

6. Stiell IG, Nesbitt LP, Nichol G, Maloney J, Dreyer J, Beaudoin T, Blackburn J, Wells GA, OPALS(2009): Study Group: Comparison of the Cerebral Performance Category score and the Health Utilities Index for survivors of cardiac arrest. Ann. Emerg. Med., 53(2):241-248.

7. Ajam K, Gold LS, Beck SS, Damon S, Phelps R, Rea TD (2011): Reliability of the Cerebral Performance Category to classify neurological status 
among survivors of ventricular fibrillation arrest: a cohort study. Scand. J. Trauma Resusc. Emerg. Med., 19:38.

8. Martins GA, Kawamura MT, Da Costa Carvalho MDG (2000): Detecting of DNA in the plasma of septic patients. Ann. N. Y. Acad. Sci., 906:134-40.

9. Zeerleder S, Zwart B, Wuillemin WA, Aarden LA, Groeneveld AB, Caliezi C, van Nieuwenhuijze AE, van Mierlo GJ, Eerenberg AJ, Lämmle B, Hack CE.(2007): Elevated nucleosome levels in systemic inflammation and sepsis. Crit Care Med 31(7):1947-51.

10. Hotchkiss RS, Nicholson DW(2006): Apoptosis and caspases regulate death and inflammation in sepsis. Nat. Rev. Immunol., 6(11):813-22.

11. Lui YY, Woo KS, Wang AY, Yeung CK, Li PK, Chau E, Ruygrok P, Lo YM (2003): Origin of plasma cell-free DNA after solid organ transplantation. Clin. Chem., 49(3):495-6.

12. Fu YW, Wang WG, Zhou HL, Cai L(2006): Presence of donorand-recipient-derived DNA microchimerism in the cell-free blood samples of renal transplantation recipients associates with the acceptance of transplanted kidneys. Asian J. Androl., 8(4):477-82.

13. Huttunen $\mathbf{R}$, Kuparinen $T$, Jylhävä J, Aittoniemi J, Vuento R, Huhtala H, Laine J, Syrjänen J, Hurme M(2011): Fatal outcome in bacteremia is characterized by high plasma cell free DNA concentration and apoptotic DNA fragmentation: a prospective cohort study. PLoS One. 6(7):e21700.

14. Kung CT, Hsiao SY, Tsai TC, Su CM, Chang WN, Huang CR, Wang HC, Lin WC, Chang HW, Lin YJ, Cheng BC, Su BY, Tsai NW, Lu CH (2012): Plasma nuclear and mitochondrial DNA levels as predictors of outcome in severe sepsis patients in the emergency room. J. Transl. Med., 10:130.

15. Wagner J2012): Free DNA--new potential analyte in clinical laboratory diagnostics? Biochem. Med. (Zagreb) 22(1):24-38.

16. Muley $T$, Ebert $W$, Stieber $P$, Raith H, Holdenrieder S, Nagel D, Fürst H, Roth HJ, Luthe H, Blijenberg BG, Gurr E, Uhl W, von Pawel J, Drings $P(\mathbf{2 0 0 3})$ : Technical performance and diagnostic utility of the new Elecsys neuron-specific enolase enzyme immunoassay. Clin. Chem. Lab. Med., 41(1):95-103.

17. Saukkonen K, Lakkisto $P$, Pettila V, Varpula M, Karlsson S, Ruokonen E, Pulkki K(2008): Cell-free plasma DNA as a predictor of outcome in severe sepsis and septic shock. Clin. Chem., 54(6):1000-7.

18. Swinkels DW, Wiegerinck E, Steegers EA, de Kok JB(2003): Effects of blood processing protocols on cell-free DNA quantification in plasma. Clin. Chem., 49(3):525-6.

19. van der Vaart M, Pretorius PJ (2010): Is the role of circulating DNA as a biomarker of cancer being prematurely overrated? Clin. Biochem., 43(1-2):26-36. 
20. Jennett B, Bond M(1975): Assessment of outcome after severe brain damage. Lancet 1(7905):480-4.

21. Sodeck GH, Domanovits H, Sterz F, Schillinger M, Losert H, Havel C, Kliegel A, Vlcek M, Frossard M, Laggner AN(2007): Can brain natriuretic peptide predict outcome after cardiac arrest? An observational study. Resuscitation 74(3):43945.

22. Angelos MG(2009): Postarrest nitric oxide effect depends on the source. Crit. Care Med., 37(1):368-9.

23. Oh SH, Kim YM, Kim HJ, Youn CS, Choi SP, Wee JH, Kim SH, Jeong WJ, Park KN(2012): Implication of cardiac marker elevation in patients who resuscitated from out-of-hospital cardiac arrest. Am. J. Emerg. Med., 30(3):464-71.

24. Ferguson LP, Durward A, Tibby SM(2012): Relationship between arterial partial oxygen pressure after resuscitation from cardiac arrest and mortality in children. Circulation 126(3):33542.

25. Saukkonen $K$, Lakkisto $P$, Varpula M, Varpula T, VoipioPulkki LM, Pettilä V, Pulkki K(2007): Association of cell-free plasma DNA with hospital mortality and organ dysfunction in intensive care unit patients. Intensive Care Med., 33(9):16247.

26. Okkonen M, Lakkisto P, Korhonen AM, Parviai-nen I, Reinikainen M, Varpula T, Pettilä V; FINNALI Study
Group (2011): Plasma cell-free DNA in patients needing mechanical ventilation. Crit. Care 15(4):R196.

27. Rainer TH, Chan AK, Lee LL, Yim VW, Lam NY, Yeung SW, Graham CA, Lo DY(2008): Use of plasma DNA to predict mortality and need for intensive care in patients with abdominal pain. Clin. Chim. Acta 398(12):113-7.

28. Arnalich F, Maldifassi MC, Ciria E, Quesada A, Codoceo R, Herruzo R, Garcia-Cerrada C, Montoya F, Vazquez JJ, López-Collazo E, Montiel C(2001): Association of cell-free plasma DNA with perioperative mortality in patients with suspected acute mesenteric ischemia. Clin. Chim. Acta 411(17-18):1269-74.

29. Rainer TH, Wong LK, Lam W, Yuen E, Lam NY, Metreweli C, Lo YM(2003): Prognostic use of circulating plasma nucleic acid concentrations in patients with acute stroke. Clin. Chem., 49(4):562-9.

30. Arnalich F, Menéndez $M$, Lagos V, Ciria E, Quesada A, Codoceo R, Vazquez JJ, LópezCollazo E, Montiel C(2010): Prognostic value of cell-free plasma DNA in patients with cardiac arrest outside the hospital: an observational cohort study. Crit. Care14(2):R47.

31. Huang CH, Tsai MS, Hsu CY, Chen HW, Wang TD, Chang WT, Ma MH, Chien KL, Chen SC, Chen WJ (2012): Circulating cell-free DNA levels correlate with postresuscitation 
survival rates in out-of-hospital cardiac arrest patients. Resuscitation 83(2):213-8.

32. Topjian AA, Lin R, Morris MC, Ichord R, Drott H, Bayer CR, Helfaer MA, Nadkarni
V(2009): Neuron-specific enolase and S-100B are associated with neurologic outcome after pediatric cardiac arrest. Pediatr. Crit. Care Med., 10(4):479-90.

\section{قياس مستويات الحمض النووي في بلازما الام والإينولاز الخاص بالخلايا العصبية بالمصل كمؤشرات لنتاج ما بعد الإنعاش لمرضى الإنى السكتة القلبية}

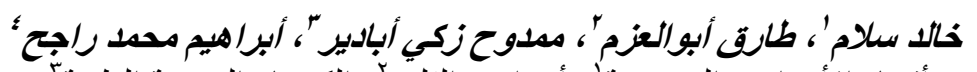

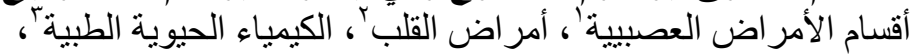

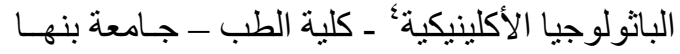

الأهداف: تقييم القيمة التوقعية لقياس مستويات الحمض النووي الديوكسي الريبوز الحر في بلازما الدم الدام

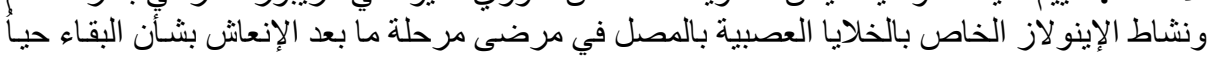
وللنتائج العصبية مقارنة بمقياس الأداء الأبناء الدماغي.

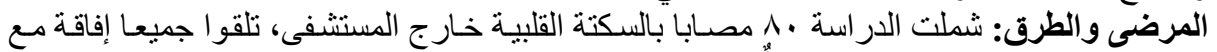

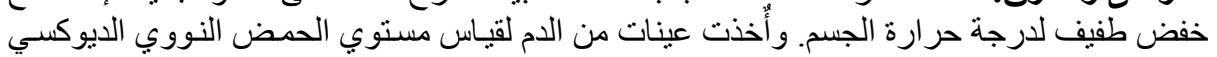

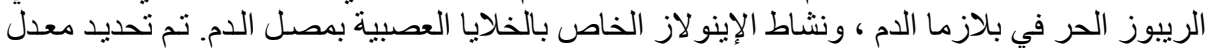

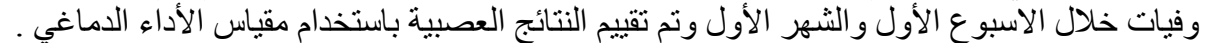

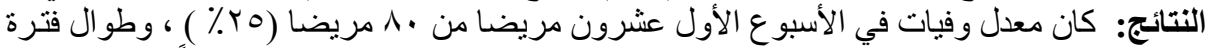

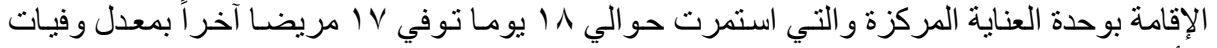

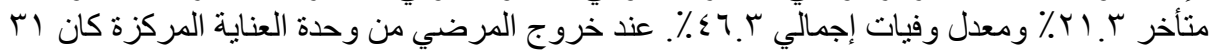

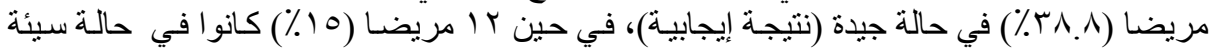

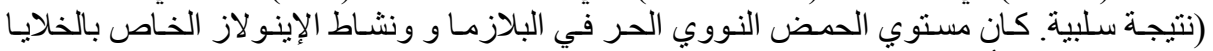

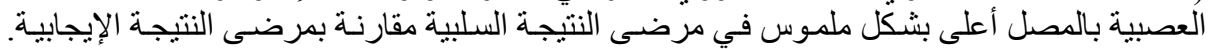

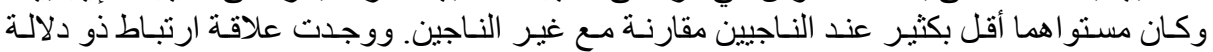

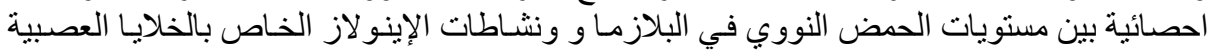

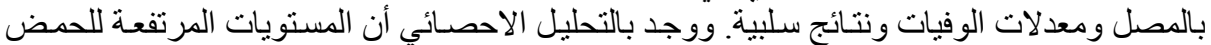

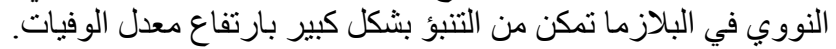

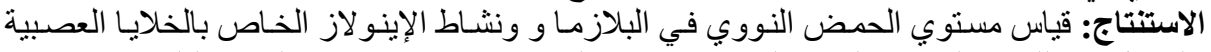
بالمصل يفيد للتنبؤ بالنجاة وبالنتائج العصبية في مرحلة ما بعد إنعاش مرضى السكتة القلبية. 